\section{TWO REPRINTS}

\section{The Ninth Bridgwater Treatise}

A Fragment. New impression of the second edition. By Charles Babbage. (Cass Library of Science Classics, No. 6.) Pp. 273. (London: Frank Cass and Co., Ltd., 1967. First published 1837.) $90 s$.

\section{Philosophical Experiments and Observations}

By Robert Hooke. Edited by W. Derham. (Cass Library of Science Classics, No. 8.) Pp. 391. (London: Frank Cass and Co., Ltd., 1967. First published 1726.) 90s.

THERE is now an almost bewildering variety of facsimile reprints of scientific works of historical interest. Inevitably, many duplications occur and the price of these books is high. The Cass Library of Science has published several of the less hackneyed works and their price is relatively modest. Most commendably they have supplied information often neglected. Thus they date their reprints and give brief details of earlier editions, and their general editor, Dr Laurens Laudan, has added an index or analytical table of contents to each volume which makes the books more usable than the original editions. $\mathrm{He}$ has also added an explanatory note to the Hooke volume. The books are sturdy and well reproduced.

Unfortunately these two volumes are not of much importance. Philosophical Experiments and Observations represents minor Hooke at best, what was left in his papers after Waller had published The Posthumous Works. Here are miscellaneous notes, jottings and letters, random, disconnected and incomplete, about one-third not by Hooke. However, many of these notes illuminate both Hooke's activities and those of his contemporaries.

Charles Babbage's Ninth Bridgwater Treatise is very much a work of its period, the 1830 s, when the "argument from design" was thought worthy of eight separate treatises, paid for by a bequest from the Earl of Bridg. water. Babbage, perhaps piqued at not being asked to write an official troatise, wrote this brief and truncated discussion illustrated by probability theory and the calculating machine. It is a curious but specialized work, more interesting to historians than scientists.

marie boas hall

\section{OBITUARIES}

\section{Dr A. T. Waterman}

Aran Tower Waterman, who died at the end of last year, did much for science in the United States. During the fifteen years when he served, first as Chief Scientist of the Office of Naval Research and later as Director of the National Science Foundation, he worked constantly in the cause of basic research and education in the sciences.

$\mathrm{He}$ was born at Cornwall-on-Hudson, New York, in 1892, and did both his undergraduate and graduate work at Princeton, receiving the degrees of $\mathrm{AB}$ in 1913, $\mathrm{MA}$ in 1914 and $\mathrm{PhD}$ in physies in 1916. His research included investigations of the conduction of electricity through solids; thermionic, photoelectric emission and related effects, and electrical properties of solids. After receiving his degree, he became an instructor in physics at the University of Cincinnati. During the First World War he spent two years with the Science and Research Division of the Army Signal Corps, where he was engaged in meteorological work. At the end of the war he joined the faculty of Yale University and stayed at the department of physics until 1942

From 1941 to 1945 Waterman was associated with the Office of Scientific Research and Development (OSRD), and from 1946 to 1951 was Deputy Chief and Chief Scientist of the newly established Office of Naval Research (ONR), Department of the Navy. He was one of the prin. cipal architects of the policies and programmes of ONR in supporting scientific research. He interpreted broadly the types of research which were important to the navy, and provided a means of supporting fundamental research that might otherwise not have been supported at a time when the Federal Government's resources were eoncentrated on applied scienco, chiefly concerned with defence and atomic energy. Under Waterman the ONR sought advice from scientific organizations, and when $n$ ecessary established advisory committees outside the navy.

The Office of Naval Research became a model for government support of basic research, and pointed out the need for a national foundation to support this kind of research, but on an even broader basis.

On April 6, 1951, President Truman appointed Waterman the first director of the newly formed National Science Foundation, for a six year term. In 1957 President Eisenhower reappointed him to this post, and although he reached the compulsory retirement age before the end of his second term Waterman continued in his post until June 1963, at the special request of President Kennedy.

While he was in charge of the National Science Foundation, Waterman not only stressed the importance of supporting, through the universities, pure research which was not of immediate significance, but he also encouraged the social sciences, and there was a steady growth in support for these subjects.

He always stressed the importance of education and training for scientists, and through a gradually expanding programme of fellowships the Foundation has sought to make graduate training available to all the best students. In 1953 the first projects began with summer institutes for teachers of high school and college mathematics and science, and curricula for schools and colleges have since been revised. While at the National Science Foundation, Waterman was able to inform the public of the importance of education and research. From Congress he obtained an initial grant of 3.5 million dollars which had increased to 40 million dollars by 1957 .

After retiring, Waterman maintained an active interest in science and education by serving on numerous boards and committees including the Board of Trustees of Atoms for Peace Awards; the Advisory Board of Georgetown University Center for Strategic Studies and the Liaison Committee on Science and Technology of the US Library of Congress. He was special consultant to the President of the National Academy of Science and chairman of the Committee on Scholarly Communication with Mainland China; consultant to the Administrator of the National Aeronautics and Space Agency and a member of its Historical Advisory Committee.

Waterman was a fellow of the American Association for the Advancement of Science, and served as president in 1963 and chairman of the board in 1964. He also belonged to the American Physical Society and the New York Academy of Sciences. He was a member of the American Association of University Professors, the American Institute of Electrical Engineers, the American Rocket Society, the American Polar Society, the Washington Academy of Sciences, the Washington Academy of Medicine, Phi Beta Kappa, Sigma Xi, the Scientific Research Society of America, and the Washington Philosophical Society. In October 1967, the American Institute of Physics awarded him the Karl Taylor Compton gold medal for distinguished statesmanship in science.

Waterman was an accomplished musician-he mastered the Scottish bagpipes and for many years played the violin, cello and viola in a string quartet, first established during his undergraduate days at Princeton University and later composed of his Washington scientific colleagues. He also frequently entertained his associates on the piano and guitar. Another great interest was his love of the woods. He was a licensed guide in the State of Maine, and he continued this activity whenever his official duties permitted a rare canoe or camping trip. 